\title{
EZİNE ESKİ KAŞAR PEYNİRİNİN KARAKTERİSTİK BAZI ÖZELLİKLERİ
}

\author{
Muhammed Ali Doğan, Yonca Karagül Yüceer* \\ Çanakkale Onsekiz Mart Üniversitesi, Mühendislik Fakültesi, Gıda Mühendisliği Bölümü, Çanakkale, Türkiye \\ Geliş / Received: 05.03.2019; Kabul / Accepted: 24.06.2019; Online bask1 / Published online: 04.09.2019
}

Doğan, M. A., Karagül Yüceer, Y. (2019). Ezine eski kaşar peynirinin karakteristik bazı özellikleri. GIDA (2019) 44 (5): 849-860 doi: 10.15237/gida.GD19052

Doğan, M. A., Karagül Yüceer, Y. (2019). Some characteristic properties of Ezine aged kasar cheese. GIDA (2019) 44 (5): 849-860 doi: 10.15237/gida.GD19052

\section{ÖZ}

Çalışmada, Ezine ve Bayramiç ilçelerinde bulunan mandıralarda üretilen Ezine eski kaşar peynirlerinin bazı fiziksel, kimyasal ve duyusal özelliklerinin belirlenmesi amaçlanmıştır. Peynirlerin genel bileşiminin farklı olduğu, renk ölçümleri ve toplam serbest aminoasit, hidrolitik ransidite ve olgunlaşma düzeyleri arasında da farklıllklar olduğu görülmüştür. Özellikle, peynirlerin sertlik ve sakızımsıllk ölçümleri arasında geniş varyasyon olduğu saptanmıştır. Peynirlerde belirlenen karakteristik bazı duyusal terimleri pişmiş, peyniraltı suyu, kremamsı, sülfür, ransit, tuzlu ve umamidir. Uçucu bileşen kompozisyonunun belirlenmesi için altı peynir örneği seçilmiştir. Aldehitler, ketonlar, alkoller, asitler ve esterler analiz edilen peynirlerde belirlenen yaygin uçucu bileşenlerdir.

Anahtar kelimeler: Ezine eski kaşar peyniri, fiziksel ve kimyasal özellikler, uçucu bileşen, duyusal.

\section{SOME CHARACTERISTIC PROPERTIES OF EZINE AGED KASAR CHEESE}

\section{ABSTRACT}

In this study, it was aimed to determine some physical, chemical and sensory properties of Ezine aged Kasar cheeses produced in cheese plants located in Ezine and Bayramiç towns of Çanakkale. It was determined that general composition of the cheeses were different and differences were seen in color measurements and total free amino acids, hydrolytic rancidity and ripening levels of the cheeses. Specifically, wide variation was detected in hardness and gumminess measurements of the cheeses. Cooked, whey, creamy, sulfur, rancid, salty and umami were some characteristic sensory terms determined in the cheeses. Six cheese samples were selected for determination of volatile compound composition. Aldehydes, ketones, alcohols, acids and esters were the common volatile compounds in the cheeses analyzed. Some terpenes including pinene and limonene were also found in the cheeses. Keywords: Ezine aged kasar cheese, physical and chemical properties, volatile compound, sensory.

\footnotetext{
* Yazışmalardan sorumlu yazar / Corresponding author;

$\triangle$ yoncayuceer@comu.edu.tr, $\quad$ (+90) 286218 0018/2272, 㚗 (+90) 2862180541
} 


\section{GİRIŞ}

Eski kaşar peyniri, "üretildikten sonra kendine has özellikleri kazanması için belirli koşullarda en az 90 gün süreyle olgunlaştırllip piyasaya sürülen peynirdir" şeklinde tanımlanmaktadır (TSE, 1999). Ezine eski kaşar peyniri de bu peynir sınıfina dahil bir peynir olup Çanakkale iline bağlı Ezine, Ayvacık ve Bayramiç ilçelerinin yer aldığ1 bölgeden toplanan sütün işlenmesi ile üretilmekte ve olgunlaştırıldıktan sonra tüketime sunulmaktadır. Bölgede genellikle Trakya eski kaşarı olarak satışa sunulmaktadır. Peynir yapımında süt karışımı, doğal şirden mayası ve deniz tuzunun dışında herhangi bir katkı maddesi kullanılmamaktadır. Tekerlek halindeki peynirlerin beş tanesi çuvallara yerleştirilerek belirli koşullarda soğuk hava deposunda olgunlaştırılmaktadır.

Ezine eski kaşar peynirinin üretimi için belirtilen coğrafi bölgeden sağlanan süt seperatörden geçirildikten sonra mayalama sicaklı̆̆ına (32-36 $\left.{ }^{\circ} \mathrm{C}\right)$ kadar isitilarak tekneye alınır ve mayalanır. Peynir mayası ilave edilmiş sütün yaklaşık 45-60 dakika pihtılaşması beklenir ve oluşan pihtı leblebi tanesi büyüklügünde kırllır. Peyniraltı suyu alındiktan sonra teleme 45-75 dakika baskıda bekletildikten sonra kesilerek asitlik gelişimi için tekneye alınır. Paslanmaz delikli kovalarla haşlama suyuna daldırllarak teleme haşlanır ve elastikiyet kazanması sağlanır. Daha sonra elastik kıvam kazanan peynirler tuz ilave edilerek yoğrulur ve kalıplanır. Kalıplanan peynirler bir gün boyunca kalıplarda bekletilip soğuduktan sonra yaklaşı 15 $20{ }^{\circ} \mathrm{C}$ olan ön olgunlaştırma odasına alınır ve kalıplardan çıkarllır. İlerleyen günlerde peynir tekerlerinin etrafinda küf gelişimi ve kabuk benzeri yap1 oluşur. Peynirlerin kenar kısımları yıkanıp küfler temizlendikten sonra çuvallara konarak olgunlaştırilır. Bu çalışmada amaç, bölgede faaliyet gösteren sınırlı sayıdaki işletme tarafindan üretilen geleneksel bir peynir çeşidimiz olan Ezine eski kaşar peynirinin karakteristik özelliklerinin ortaya konmasıdır.

\section{MATERYAL VE YÖNTEM}

Çalışmada farklı süt türleri ve olgunluk düzeylerine sahip toplam 20 Ezine eski kaşar peyniri beş üretici firmadan temin edilmiştir. Bu örneklerden altı tanesi duyusal özelliklerine göre seçilerek uçucu bileşen analizlerinde kullanılmıştır.

\section{Peynirlerin bileşimi ve fizikokimyasal analizler}

Peynirlerde \% asitlik (Metin, 2006), kurumadde (TS, 1989), yağ (TS, 1978), pH ve tuz (Bradley vd., 1992), kül ve toplam protein (AOAC, 2000) belirlenmiştir. Örneklerde suda çözünür azot oranı (SÇA), Kuchroo ve Fox (1982)'a göre \% 12'lik TCA'da çözünen azot miktarı da Polychroniadou vd. (1999) tarafindan önerilen yönteme göre tespit edilmiştir. \% 5 PTA'da çözünen azot miktarı Jarrett vd. (1982) tarafindan önerilen yöntemle belirlenmiştir. Peynirlerde hidrolitik ransidite titrimetrik metotla (Renner, 1986), toplam serbest aminoasitlik Folkerstma ve Fox (1992) tarafindan uygulandığı biçimiyle tespit edilmiştir.

Peynirin renk analizi Minolta Renk Ölçüm cihazı (Bhale vd., 2003), tekstürel özellikleri Tekstür Analizörü (Brookfield CT3, İngiltere) kullanılarak belirlenmiştir.

Uçucu bileşenlerin belirlenmesi amaciyla Gaz Kromatografisi-Kütle Spektrometresi (GC-MS) (GC 6890, MS 6890 N, Agilent Technologies, Wilmington, DE, ABD) kullanılmıştır.

Peynirlerde bulunan uçucu bileşenler katı faz mikroekstraksiyon yöntemi (SPME) ile izole edilmiş ve DB-5 (30 m uzunluk $\times 0,32 \mathrm{~mm}$ iç çap (i.d.) $\times 0,25 \mu \mathrm{m}$ film kalınlığ1) kolona enjekte edilmiştir (J\&W Scientific, Folsom, California, ABD). Analizlerde $2 \mathrm{~g}$ peynir $40 \mathrm{~mL}$ SPME vialine (Supelco, Bellafonte, ABD) alınıp içine 2 $\mathrm{mL}$ saf su, $1 \mathrm{~g}$ sodyum klorür ve $5 \mu \mathrm{L}$ iç standart (1 mL'sinde $0.1 \mu \mathrm{L} 2$-metil valerik asit ve $0,6 \mu \mathrm{L}$ 2-metil-3-heptanon bulunmaktadır) ilave edilerek $40{ }^{\circ} C^{\prime}$ lik su banyosunda (GFL, Model 1103, Burgwedel, Almanya) 20 dakika süreyle bekletilmiştir. Sonra SPME fiber $(2 \mathrm{~cm}-50 / 30 \mu \mathrm{m}$ DVB/Carboxen/PDMS stable flex Supelco, Belafonte, ABD) viale batırllip 20 dakika daha 40 ${ }^{\circ} \mathrm{C}$ 'lik su banyosunda bekletilmiş ve GC-MS'e enjekte edilmiştir. Taşıyıcı gaz akış1 $1.2 \mathrm{~mL} / \mathrm{dk}$, firın programı başlangıç sıcaklı̆̆ $40^{\circ} \mathrm{C}$ 'de 1 dakika olup $4{ }^{\circ} \mathrm{C} / \mathrm{dk}$ ramp ile $250{ }^{\circ} \mathrm{C}$ son sicakllğa ulaşılmış ve 15 dakika bekletilmiştir. MS şartları 
ise; kapiler ara yüz sıcaklığ $1280{ }^{\circ} \mathrm{C}$, iyonizasyon enerjisi: $70 \mathrm{eV}$ : kütle aralı̆g 35-350 amu, tarama hız1 $4.45 \mathrm{scan} / \mathrm{s}$ 'dir. Uçucu bileşenlerin tespitinde National Institute of Standards and Technology (NIST, 2008) ve Wiley Registry of Mass Spectral Data (Wiley, 2005) kütüphaneleri kullanılmıştır. Uçucu bileşenlerin miktar belirlenmesi ise oransal bolluklarına göre (Avsar vd., 2004) belirlenmiştir.

\section{Duyusal analizler}

Peynirlerin tanımlayıc1 duyusal özellikleri, eğitilmiş ve yaşları 25-50 arasında değişen 6 panelist (4 bayan, 2 erkek) tarafindan Spectrum ${ }^{T M}$ yöntemi kullanılarak belirlenmiştir (Meilgaard vd., 1999). Değerlendirecek panelistler peynir ve süt ürünlerinde duyusal değerlendirmeler konusunda yaklaşık 50 saat eğitim almışlardır. Eğitim, ölçülendirme çalışmaları ve değerlendirmeler için 15 puanlı skala kullanılmıştır. Peynirler panelistlere 15-20 g'lık porsiyonlar halinde sunulmuş ve panelistlerin ağzını nötürlemesi için ekmek ve su kullanılmışır.

\section{İstatistiksel Analiz}

Peynirlerin fiziksel, kimyasal ve duyusal bazı özelliklerinin ortaya konması, peynirler arasındaki farkllik ve benzerliklerin belirlenebilmesi amacıyla Çok Boyutlu Ölçeklendirme Analizi (Multidimensional Scaling) kullanılmıştır (Kruskal, 1964; Baspinar vd., 2000).

\section{BULGULAR VE TARTIŞMA}

Peynir örneklerinin olgunluk düzeyi, asitlik ve genel bileşimi Çizelge 1 ve 2'de sunulmuştur. Peynirlerden beş tanesi (E1, E4, E5, E6, E7) inek sütü kullanılarak üretilmiş olup diğer peynirlerin üretiminde koyun, keçi ve inek sütleri birlikte kullanılmıştır. Peynirlerin olgunluk düzeyi ise 4 ve 20 ay arasında değişmektedir (Çizelge 1 ve Çizelge 2). Peynirlerin titrasyon asitliği \% 0.67-1.21, $\mathrm{pH}$ değerleri 5.14-5.79, kül \% 3.84-5.48, kurumadde $\%$ 54.27-64.66, tuz \% 2.10-4.10, protein \% 23.9929.24, yağ \% 23.11-28.96 arasında değişmektedir. En yüksek pH değeri 5.79 ile E11 numaralı peynir, en düşük $\mathrm{pH}$ değeri ise 5.14 ile E6 numaralı peynirde olduğu tespit edilmiştir. Olgunlaşma aşamasında belirli bir dönemden sonra meydana gelen amonyak, karbonil bileşikleri vb. bazik bileşikler sebebiyle (McSweeney vd., 1993; Yüzbaş1, 1996) veya organik asitlerin metabolizması ve aminoasitlerin deaminasyonu sonucunda pH'nın değişim gösterdiği bildirilmektedir (Madkor vd., 1987). Peynirlerde en yüksek titrasyon asitliği ölçümünün \% 1.21 ile E9 numaralı peynirde, en düşük asitliğin \% 0.67 ile E7 numaralı peynirde olduğu saptanmıştır. Olgunlaşma süresi uzun olan peynirlerde titrasyon asitliğinin genel olarak yüksek olduğu tespit edilmiştir. Örneğin, E4 ve E9 numaralı peynirlerin olgunlaşma süreleri uzun olup titrasyon asitlikleri de yüksek bulunmuştur (Çizelge 1).

Ezine eski kaşar peynirlerinde kurumadde içeriği $\%$ 54.27-64.66, yağ içeriği de \% 23.11-28.96 arasında değişmektedir (Çizelge 1). Kurumadde oranı arttıkça \% yağ oranları da genel olarak artış göstermiştir. Kurumadde oranı en düşük peynirlerden olan E10 peyniri en düşük yă̆ oranina sahiptir. E9, E11 ve E13 peynirleri de hem yüksek kurumadde hem de yüksek yă̆ oranına sahiptir. Peynirlerde tuz oranı en yüksek olan \% 4.10 ile E15 numaralı peynir, en düşük oranda tuz ise \% 2.10 ile E10 numaralı peynir olmuştur (Çizelge 1). Olgunlaşma süresi uzun olan peynirlerde tuz oranının genel olarak yüksek olduğu tespit edilmiştir. Örneğin, E2, E9, E11 ve E13 numaralı peynirlerin olgunlaşma süreleri uzun olup tuz oranları da yüksek bulunmuştur. Kül analizleri sonucunda peynirlerde kül oranının $\%$ 3.84-5.48 arasında değiştiği belirlenmiştir. Olgun kaşar peynirleri üzerine yapılan diğer çalışmalarda da (Yaşar, 2000; Aydemir, 2010; Doğan, 2010; Kesenkaş vd., 2009) benzer sonuçlar elde edilmiştir.

Ezine eski kaşar peynirinde protein, azot fraksiyonları ve hidrolitik ransidite değerleri Çizelge 2'de sunulmuştur. Peynirlerde belirlenen SÇA, TCA, PTA ve TSA değerleri olgunlaşma süresince proteoliz düzeyini göstermektedir. Ezine eski kaşar peynirlerinde en yüksek SÇA oranı \% 1.02 ile E14 numaralı peynir örneği ve en düşük SÇA oranı $\% 0.39$ ile E1 numaralı peynir örneğine aittir (Çizelge 2). Olgunlaşma süresi uzun olan E13 ve E15 numaralı peynirlerde proteoliz düzeyi de yüksek bulunmuştur. Koca (2002), 90 gün boyunca olgunlaştırdığ1 kaşar peynirlerinde SÇA değerinin 0.18-0.43 arasında olduğunu belirlemiştir. 
Çizelge 1. Ezine eski kaşar peynirlerinde asitlik ve bileşim $(\mathrm{n}=20)$ (ortalama \pm standart hata) Table 1. Acidity and composition in Ezine aged kasar cheeses ( $n=20)$ (Mean $\pm S . E)$

\begin{tabular}{|c|c|c|c|c|c|c|c|}
\hline $\begin{array}{l}\text { Peynir } \\
\text { Cheese }\end{array}$ & $\begin{array}{c}\text { Olgunlaşma/ripening } \\
\text { (ay/mount) ve/ and } \\
\text { Süt/Milk }\end{array}$ & $\mathrm{pH}^{*}$ & $\begin{array}{c}\% \text { T. } \mathrm{A}^{*} \\
\text { T.A \% }\end{array}$ & $\begin{array}{l}\% \mathrm{~K} . \mathrm{M} \\
D . M \% \\
\end{array}$ & $\begin{array}{l}\% \text { Tuz } \\
\text { Salt } \%\end{array}$ & $\begin{array}{l}\% \text { Yă̆ } \\
F a t \%\end{array}$ & $\begin{array}{l}\% \text { Kül } \\
A s h \%\end{array}$ \\
\hline E1 & $9-\dot{I}$ & 5.44 & 0.86 & $59.16 \pm 0.19$ & $2.51 \pm 0.01$ & $28.08 \pm 0.37$ & $4.80 \pm 0.01$ \\
\hline E2 & 16-K-K-İ & 5.40 & 0.82 & $60.55 \pm 0.29$ & $3.34 \pm 0.01$ & $28.83 \pm 0.37$ & $4.23 \pm 0.00$ \\
\hline E3 & 16-K-K-İ & 5.32 & 0.82 & $60.66 \pm 0.50$ & $3.56 \pm 0.01$ & $28.94 \pm 0.27$ & $4.76 \pm 0.01$ \\
\hline E4 & $20-\dot{I}$ & 5.27 & 0.93 & $61.32 \pm 0.17$ & $3.02 \pm 0.00$ & $26.72 \pm 0.27$ & $4.88 \pm 0.00$ \\
\hline E5 & $20-\dot{I}$ & 5.31 & 0.86 & $60.22 \pm 0.03$ & $2.98 \pm 0.01$ & $26.55 \pm 0.37$ & $4.74 \pm 0.02$ \\
\hline E6 & $20-\dot{I}$ & 5.14 & 0.93 & $59.86 \pm 0.01$ & $2.97 \pm 0.01$ & $26.71 \pm 0.28$ & $4.43 \pm 0.00$ \\
\hline E7 & $9-\dot{I}$ & 5.49 & 0.67 & $60.22 \pm 0.15$ & $2.75 \pm 0.01$ & $28.72 \pm 0.47$ & $4.50 \pm 0.01$ \\
\hline E8 & 16-K-K-İ & 5.58 & 0.68 & $60.14 \pm 0.37$ & $2.74 \pm 0.01$ & $26.70 \pm 0,26$ & $4.88 \pm 0.03$ \\
\hline E9 & 9-K-K-İ & 5.56 & 1.21 & $64.66 \pm 0.55$ & $3.44 \pm 0.01$ & $28.63 \pm 0.25$ & $5.48 \pm 0.02$ \\
\hline E10 & 5-K-K-İ & 5.35 & 1.02 & $55.46 \pm 0.01$ & $2.10 \pm 0.00$ & $23.11 \pm 0.11$ & $3.93 \pm 0.01$ \\
\hline E11 & 9-K-K-İ & 5.79 & 0.89 & $62.32 \pm 0.04$ & $3.41 \pm 0.01$ & $28.96 \pm 0.22$ & $4.78 \pm 0.03$ \\
\hline E12 & 5-K-K-İ & 5.32 & 1.03 & $55.16 \pm 0.21$ & $3.30 \pm 0.00$ & $25.23 \pm 0.23$ & $4.64 \pm 0.00$ \\
\hline E13 & 16-K-K-İ & 5.30 & 0.87 & $62.09 \pm 0.00$ & $3.59 \pm 0.00$ & $28.23 \pm 0,24$ & $5.38 \pm 0.01$ \\
\hline E14 & 5-K-K-İ & 5.65 & 0.95 & $54.27 \pm 0.16$ & $2.85 \pm 0.00$ & $24.35 \pm 0.11$ & $3.84 \pm 0.01$ \\
\hline E15 & 16-K-K-İ & 5.21 & 0.97 & $61.54 \pm 0.09$ & $4.10 \pm 0.01$ & $27.09 \pm 0.12$ & $5.26 \pm 0.01$ \\
\hline E16 & 4-K-K-İ & 5.24 & 1.06 & $60.06 \pm 0.07$ & $3.02 \pm 0.00$ & $26.21 \pm 0.23$ & $4.20 \pm 0.01$ \\
\hline E17 & 4-K-K-İ & 5.16 & 0.94 & $59.66 \pm 0.07$ & $3.12 \pm 0.00$ & $26.11 \pm 0.12$ & $3.96 \pm 0.01$ \\
\hline E18 & 4-K-K-İ & 5.17 & 0.89 & $59.62 \pm 0.30$ & $2.78 \pm 0.01$ & $27.83 \pm 0.09$ & $4.34 \pm 0.02$ \\
\hline E19 & 4-K-K-İ & 5.46 & 1.03 & $58.56 \pm 0.34$ & $3.64 \pm 0.00$ & $25.47 \pm 0.24$ & $4.66 \pm 0.02$ \\
\hline E20 & 4-K-K-İ & 5.66 & 0.99 & $58.41 \pm 0.14$ & $3.01 \pm 0.01$ & $28.94 \pm 0.23$ & $3.88 \pm 0.01$ \\
\hline & Min. & 5.14 & 0.67 & $54.27 \pm 0.16$ & $2.10 \pm 0.00$ & $23.11 \pm 0.11$ & $3.84 \pm 0.01$ \\
\hline & Mak./Max & 5.79 & 1.21 & $64.66 \pm 0.55$ & $4.10 \pm 0.01$ & $28.96 \pm 0.22$ & $5.48 \pm 0.02$ \\
\hline & Ort./Mean & 5.39 & 0.92 & $59.70 \pm 0.18$ & $3.14 \pm 0.00$ & $27.07 \pm 0.24$ & $4.58 \pm 0.01$ \\
\hline
\end{tabular}

E: Ezine eski kaşar peyniri. S. E.:Standart hata, K: Koyun sütü, K: Keçi sütü, İ: İnek sütü, T.A: Titrasyon Asitliği, K.M: Kurumadde, Min: Minimum, Mak.: Maksimum, Ort.: Ortalama. *:Standard hata $<0.01$.

E: Ezine aged kasar cheese, S.E: standard error, K:Sheep, K: Goat, I: Cow, T.A: Titratable acidity, K.M.: Dry matter, Min.: Minimum, Max.: Maximum, Ort: Mean. *:Standard error $<0.01$.

Ezine eski kaşar peynirlerinde en yüksek TCA oranının \% 0.85 ile E20 numaralı peynirde, en düşük TCA oranı $\% 0.20$ ile E8 numaralı peynirde olduğu saptanmıştır. E11, E14, E19 ve E20 numaralı peynirlerin proteolitik aktivitesi yüksektir. Uzun süre olgunlaşan peynirlerde proteolitik aktivitenin yüksek olduğu tespit edilmiştir. Say (2008), 90 gün olgunlaştırdığı kaşar peynirlerinde TCA değerini $0.04-0.23$ arasında, Yaşar (2007), 90 gün olgunlaştırdığ1 kaşar peynirinde TCA değerini $0.04-0.14$ arasında belirlemiştir.
Ezine eski kaşar peynirlerinde en yüksek PTA oranı \% 0.35 ile E20 numaralı peynirde, en düşük PTA oran1 \% 0.04 ile E1, E2 ve E6 numaralı peynirlerde tespit edilmiştir. E7, E9 ve E11 numaralı peynirlerin proteolitik aktivitelerinin yüksek olduğu saptanmış olup bu peynirlerin olgunluk süreleri de uzundur. Yaşar (2007), 90 gün olgunlaştırdığ1 kaşar peynirlerinin PTA değerinin $\quad 0.02-0.06$ arasinda olduğunu belirlemiştir.

Ezine eski kaşar peynirlerinde en yüksek toplam serbest aminoasit değerinin $16.30 \mathrm{mg} \mathrm{Leu/g}$ ile 
E9 numaralı peynirde, en düşük toplam serbest aminoasit değerinin ise E15 numaralı peynirde olduğu tespit edilmiştir (Çizelge 2). Bu sonuçlara göre E6, E7 ve E9 numaralı peynirlerde toplam serbest aminoasit değerleri yüksek bulunmuş, bu peynirlerde olgunluk süreleri uzun ve proteoliz düzeylerinin genel olarak yüksek olduğu saptanmıştır. Say (2008), 90 gün olgunlaştırdığ kaşar peynirlerinde TSA değerlerinin 6.95-38.95 mg Leu/ g arasinda, Yaşar (2007), 90 gün olgunlaştırdığ1 kaşar peynirlerinin TSA değerlerinin 0.74-3.57 mg Leu/ $g$ arasinda, Temizkan (2012), 90 gün boyunca olgunlaştırdığ1 kaşar peynirlerinde TSA değerlerinin 0.15-1.54 $\mathrm{mg} \mathrm{Leu/g}$ arasında olduğunu tespit etmiştir.

Çizelge 2. Peynirlerin protein, azot fraksiyonları, serbest aminoasit ve hidrolitik ransidite sonuçları $(\mathrm{n}=20)$ (ortalama \pm standart hata)

Table 2. Protein, nitrogen fractions, free amino acids and bydrolytic rancidity results of the cheeses $(n=20)$ (Mean \pm S.E)

\begin{tabular}{|c|c|c|c|c|c|c|}
\hline Peynir & $\%$ Protein & $\% \mathrm{SÇA}^{*}$ & $\% \mathrm{TCA}^{*}$ & $\%$ PTA $^{*}$ & TSA (mg Leu/g) & $\begin{array}{c}\text { ADV } \\
\text { (meq KOH/ } 100 \text { g yağ) }\end{array}$ \\
\hline E1 & $24.85 \pm 0.16$ & 0.39 & 0.31 & 0.04 & $6.68 \pm 0.56$ & $2.89 \pm 0.07$ \\
\hline E2 & $26.02 \pm 0.20$ & 0.46 & 0.22 & 0.04 & $5.15 \pm 0.46$ & $6.55 \pm 0.07$ \\
\hline E3 & $25.53 \pm 0.20$ & 0.41 & 0.24 & 0.05 & $3.68 \pm 0.10$ & $3.59 \pm 0.07$ \\
\hline E4 & $28.38 \pm 0.28$ & 0.53 & 0.42 & 0.11 & $8.47 \pm 0.66$ & $6.76 \pm 0.07$ \\
\hline E5 & $27.60 \pm 0.17$ & 0.45 & 0.36 & 0.13 & $9.09 \pm 0.17$ & $6.34 \pm 0.07$ \\
\hline E6 & $27.33 \pm 0.23$ & 0.55 & 0.38 & 0.04 & $12.26 \pm 0.29$ & $5.60 \pm 0.03$ \\
\hline E7 & $25.57 \pm 0.16$ & 0.61 & 0.42 & 0.16 & $12.71 \pm 0.21$ & $4.54 \pm 0.03$ \\
\hline E8 & $26.92 \pm 0.06$ & 0.48 & 0.20 & 0.09 & $3.10 \pm 0.31$ & $3.45 \pm 0.07$ \\
\hline E9 & $29.24 \pm 0.11$ & 0.76 & 0.49 & 0.16 & $16.30 \pm 0.94$ & $3.03 \pm 0.07$ \\
\hline E10 & $27.20 \pm 0.02$ & 0.85 & 0.53 & 0.14 & $15.45 \pm 0.46$ & $3.56 \pm 0.03$ \\
\hline E11 & $27.26 \pm 0.12$ & 0.59 & 0.56 & 0.22 & $9.99 \pm 0.42$ & $3.48 \pm 0.10$ \\
\hline E12 & $23.99 \pm 0.09$ & 0.47 & 0.45 & 0.07 & $6.26 \pm 0.35$ & $6.27 \pm 0.07$ \\
\hline E13 & $27.00 \pm 0.18$ & 0.82 & 0.25 & 0.10 & $2.53 \pm 0.01$ & $3.77 \pm 0.03$ \\
\hline E14 & $24.83 \pm 0.13$ & 1.02 & 0.64 & 0.26 & $8.71 \pm 0.23$ & $3.31 \pm 0.07$ \\
\hline E15 & $27.98 \pm 0.15$ & 0.82 & 0.28 & 0.09 & $2.50 \pm 0.04$ & $3.34 \pm 0.10$ \\
\hline E16 & $28.30 \pm 0.23$ & 0.70 & 0.38 & 0.14 & $4.53 \pm 0.40$ & $5.11 \pm 0.03$ \\
\hline E17 & $28.42 \pm 0.13$ & 0.40 & 0.33 & 0.13 & $3.41 \pm 0.18$ & $5.95 \pm 0.03$ \\
\hline E18 & $26.18 \pm 0.07$ & 0.88 & 0.31 & 0.15 & $3.10 \pm 0.00$ & $3.87 \pm 0.07$ \\
\hline E19 & $27.04 \pm 0.13$ & 0.93 & 0.65 & 0.05 & $6.76 \pm 0.17$ & $6.20 \pm 0.14$ \\
\hline E20 & $24.22 \pm 0.11$ & 1.01 & 0.85 & 0.35 & $13.39 \pm 0.34$ & $3.66 \pm 0.07$ \\
\hline Min. & $23.99 \pm 0.09$ & 0.39 & 0.20 & 0.04 & $2.50 \pm 0.04$ & $2.89 \pm 0.07$ \\
\hline Mak./Max. & $29.24 \pm 0.11$ & 1.02 & 0.85 & 0.35 & $16.30 \pm 0.94$ & $6.76 \pm 0.07$ \\
\hline Ort./Mean & $26.69 \pm 0.15$ & 0.66 & 0.41 & 0.13 & $7.70 \pm 0.31$ & $4.56 \pm 0.06$ \\
\hline
\end{tabular}

E: Ezine eski kaşar peyniri, SÇA: Suda Çözünen Azot, TCA: Trikloroasetik Asitte Çözünen Azot Oranı, PTA: Fosfotungustik Asitte Çözünen Azot Oranı, TSA: Toplam Serbest Aminoasitlik, ADV: Hidrolitik Ransidite (Acid Degree Value, Min.: Minimum, Mak.: Maksimum, Ort.: Ortalama. *:Standard hata $<0.01$.

E: Ezine aged kasar cheese, S. E. : Standart error, SCA: Water soluble nitrogen ratio, TCA: $12 \%$ Tricloroacetic acid-soluble nitrogen ratio, PTA: 5 \% Phosphotungustic acid-soluble nitrogen raito, TS A: Total free amino acid, ADV: Acid degree value, Min.: Minimum, Max.: Maximum, Ort.: Mean. *:Standard error $<0.01$.

Hidrolitik ransidite (ADV) peynirlerdeki süt yağında bulunan serbest yağ asidi miktarını ve lipoliz düzeyini gösteren bir parametredir.
Peynirlerde olgunlaşma süresi uzadıkça lipolitik aktivite artmakta ve hidrolitik ransidite yükselmektedir. Peynirlerde en yüksek hidrolitik 
ransidite değeri 6.76 meq KOH/ $100 \mathrm{~g}$ yağ ile E4 numaralı peynirde, en düşük hidrolitik ransidite değeri 2.89 meq KOH/ $100 \mathrm{~g}$ yağ ile E1 numaralı peynirde tespit edilmiştir. E2, E4, E5, E12 ve E19 peynirlerinde hidrolitik ransidite değerlerinin yüksek olduğu saptanmış olup bu durum lipolitik aktivitenin de yüksek seviyede olduğunun göstergesidir. Kesenkaş vd., (2009), bitkisel yağ ekleyip 3 ay boyunca olgunlaştırdıkları kaşar peynirinde hidrolitik ransidite değerinin 1.19-2.22 meq KOH/ 100 g yağ arasında, Ürkek (2008), 3 farklı homojenizasyon basincı kullanarak üretip 90 gün olgunlaştırdığı kaşar peynirlerinde hidrolitik ransidite değerinin 0.74-5.33 meq $\mathrm{KOH} / 100 \mathrm{~g}$ yağ arasında olduğunu saptamıştır. Şekil 1'de Ezine eski kaşar peynirlerinin kimyasal analiz sonuçlarına göre geometrik dağılımı görülmektedir.

\section{Derived Stimulus Configuration}

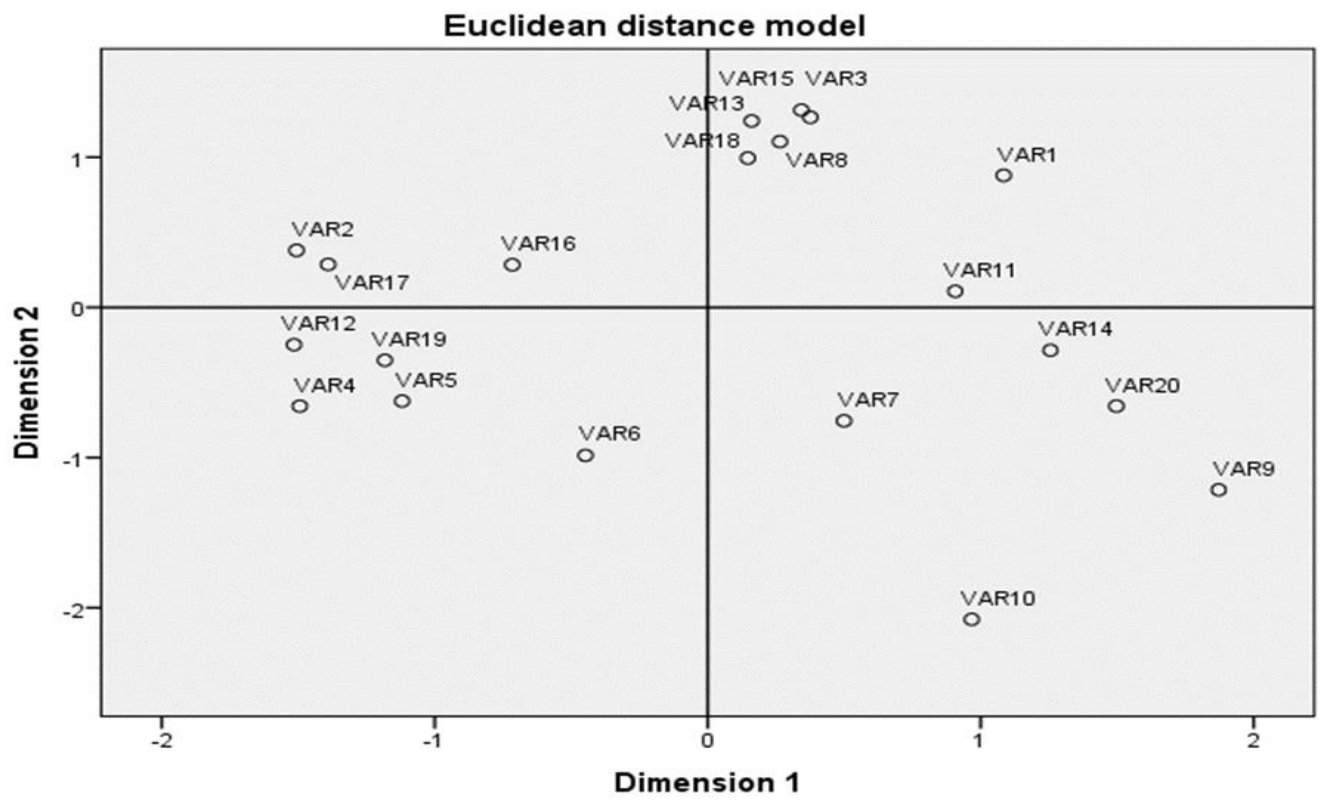

Şekil 1. Ezine eski kaşar peynirlerinin kimyasal analiz sonuçlarına göre geometrik dağılımı. VAR: Her bir peynir örneğini temsil etmektedir.

Figure 1. Geometric distribution of Ezine aged kasar cheese based on the results of chemical analysis. $V A R$ : represents each cheese.

Peynirlerde kimyasal analiz sonuçları bakımından E3, E8, E13, E15 ve E18 peynirleri aynı bölgede toplanmış olup geometrik olarak çok yakın dağılım göstermektedirler (Şekil 1). Ancak E1 ve E11 peynirleri diğerlerinde farklı görülmektedir. Özellikle E3 ve E15 peynirlerinin kimyasal analiz sonuçları incelendiğinde (Çizelge 1 ve Çizelge 2) özellikle $\mathrm{pH}$, protein, SÇA, titrasyon asitliği, TCA ve PTA değerleri bakımından birbirine benzerlik göstermektedir. E11 peynirinin farklı oluşu bu peynirin en yüksek $\mathrm{pH}$, TSA, yağ, kül, kurumadde ve protein değerlerine sahip olmasıyla açıklanabilir. E10 peynirin geometrik olarak diğer peynirlerden uzak konumda olması ise kurumaddesinin, tuz oranının, yağ ve kül içeriğinin düşük olmasına bağlanabilir. Peynirlerin olgunluk durumu, sütlerin karışım oranları, peynirlerin üretim şekli, süt türleri vb. etmenler peynirlerde bu tür farklılıkların oluşmasına neden olabilir.

Ezine eski kaşar peynirinde tekstür profil analizi ve renk analiz sonuçları Çizelge 3 'te verilmiştir. Peynirlerde en yüksek sertlik değerinin $4985.12 \mathrm{~g}$ ile E17 numaralı peynirde, en düşük sertlik değerinin ise $1921.75 \mathrm{~g}$ ile E8 numaralı peynirde, en yüksek sakızımsılık değeri 3990.37 g ile E13 numaralı peynirde, en düşük sakızımsılık değeri 
$1561.95 \mathrm{~g}$ ile E8 numaralı peynirde, en yüksek iç yapışkanlık değeri 0.85 ile E5 numaralı peynirde, en düşük iç yapışkanlık değeri 0.66 ile E20 numaralı peynirde, en yüksek elastikiyet özelliği
$2.76 \mathrm{~mm}$ ile E14 numaralı peynirde, en düşük elastikiyet özelliği $2.38 \mathrm{~mm}$ ile E16 numaralı peynirde belirlenmiştir.

Çizelge 3. Tekstür profil analizi ve renk analiz sonuçları $(\mathrm{n}=20)$ (ortalama \pm standart hata) Table 3. Texture profile analysis and color analysis results $(n=20)$ (Mean $\pm S . E)$

\begin{tabular}{lcccccc}
\hline Peynir & Sertlik $(\mathrm{g})$ & $\begin{array}{c}\text { İç yap1ş. } \\
\text { Cheese }\end{array}$ & $\begin{array}{c}\text { Elas. }(\mathrm{mm}) \\
\text { Resilience }\end{array}$ & $\begin{array}{c}\text { Sak. }(\mathrm{g}) \\
\text { Gumminess }\end{array}$ & $L^{*}$ & $b^{*}$ \\
\hline E1 & $3615.62 \pm 414$ & $0.74 \pm 0.01$ & $2.61 \pm 0.04$ & $2709.42 \pm 329$ & $77.42 \pm 0.68$ & $20.76 \pm 0.19$ \\
E2 & $3454.37 \pm 462$ & $0.71 \pm 0.01$ & $2.54 \pm 0.06$ & $2455.50 \pm 316$ & $76.72 \pm 0.82$ & $21.40 \pm 0.12$ \\
E3 & $2612.75 \pm 326$ & $0.80 \pm 0.01$ & $2.65 \pm 0.04$ & $2095.35 \pm 253$ & $81.18 \pm 0.32$ & $18.08 \pm 0.31$ \\
E4 & $4304.37 \pm 471$ & $0.84 \pm 0.03$ & $2.69 \pm 0.10$ & $3651.42 \pm 462$ & $77.80 \pm 0.40$ & $17.34 \pm 0.19$ \\
E5 & $2610.37 \pm 464$ & $0.85 \pm 0.01$ & $2.75 \pm 0.02$ & $2211.17 \pm 374$ & $76.44 \pm 0.36$ & $18.15 \pm 0.44$ \\
E6 & $2922.37 \pm 353$ & $0.84 \pm 0.01$ & $2.75 \pm 0.01$ & $2454.55 \pm 302$ & $82.51 \pm 0.26$ & $19.08 \pm 0.22$ \\
E7 & $2304.75 \pm 239$ & $0.78 \pm 0.00$ & $2.65 \pm 0.01$ & $1817.05 \pm 184$ & $80.69 \pm 0.13$ & $19.13 \pm 0.64$ \\
E8 & $1921.75 \pm 178$ & $0.81 \pm 0.01$ & $2.63 \pm 0.03$ & $1561.95 \pm 124$ & $81.57 \pm 0.19$ & $21.25 \pm 0.49$ \\
E9 & $2948.87 \pm 322$ & $0.79 \pm 0.01$ & $2.64 \pm 0.01$ & $3148.47 \pm 334$ & $73.69 \pm 0.29$ & $22.33 \pm 0.46$ \\
E10 & $3039.62 \pm 715$ & $0.80 \pm 0.02$ & $2.66 \pm 0.06$ & $2404.47 \pm 500$ & $78.83 \pm 0.28$ & $15.42 \pm 0.12$ \\
E11 & $4459.25 \pm 135$ & $0.83 \pm 0.02$ & $2.69 \pm 0.02$ & $3730.72 \pm 206$ & $72.56 \pm 0.49$ & $24.74 \pm 0.19$ \\
E12 & $4163.50 \pm 703$ & $0.78 \pm 0.01$ & $2.56 \pm 0.10$ & $3226.45 \pm 524$ & $76.37 \pm 1.09$ & $17.07 \pm 0.29$ \\
E13 & $4890.62 \pm 236$ & $0.81 \pm 0.03$ & $2.76 \pm 0.01$ & $3990.37 \pm 160$ & $83.87 \pm 0.58$ & $16.53 \pm 0.20$ \\
E14 & $3598.50 \pm 373$ & $0.81 \pm 0.01$ & $2.68 \pm 0.06$ & $2895.62 \pm 260$ & $75.93 \pm 0.58$ & $14.87 \pm 0.25$ \\
E15 & $4509.87 \pm 398$ & $0.81 \pm 0.04$ & $2.73 \pm 0.03$ & $3689.07 \pm 474$ & $82.18 \pm 0.81$ & $16.92 \pm 0.42$ \\
E16 & $3784.37 \pm 245$ & $0.75 \pm 0.01$ & $2.38 \pm 0.18$ & $2859.67 \pm 142$ & $81.87 \pm 0.29$ & $16.03 \pm 0.22$ \\
E17 & $4985.12 \pm 186$ & $0.78 \pm 0.03$ & $2.70 \pm 0.11$ & $3926.07 \pm 322$ & $75.93 \pm 0.70$ & $18.28 \pm 0.51$ \\
E18 & $4297.50 \pm 544$ & $0.77 \pm 0.01$ & $2.66 \pm 0.04$ & $3324.12 \pm 416$ & $76.97 \pm 0.66$ & $19.25 \pm 0.27$ \\
E19 & $3368.12 \pm 473$ & $0.77 \pm 0.03$ & $2.41 \pm 0.14$ & $2579.70 \pm 340$ & $80.54 \pm 0.69$ & $15.60 \pm 0.28$ \\
E20 & $3922.37 \pm 593$ & $0.66 \pm 0.03$ & $2.60 \pm 0.01$ & $2579.32 \pm 364$ & $77.11 \pm 1.66$ & $14.87 \pm 0.17$ \\
Min. & $1921.75 \pm 178$ & $0.66 \pm 0.03$ & $2.38 \pm 0.18$ & $1561.95 \pm 124$ & $72.56 \pm 0.49$ & $14.87 \pm 0.17$ \\
Mak./Max & $4985.12 \pm 186$ & $0.85 \pm 0.01$ & $2.76 \pm 0.01$ & $3990.37 \pm 160$ & $83.87 \pm 0.58$ & $24.74 \pm 0.19$ \\
Ort./Mean & $3585.70 \pm 391$ & $0.79 \pm 0.01$ & $2.64 \pm 0.05$ & $2865.52 \pm 319$ & $78.51 \pm 0.56$ & $18.36 \pm 0.29$ \\
\hline E E & & &
\end{tabular}

E: Ezine eski kaşar peyniri, İç yapış.: İç yapışkanlık, Elas.: Elastikiyet, Sak.: Sakızımsılık, Min: Minimum, Mak.: Maksimum, Ort.: Ortalama.

E: Ezine aged kasar cheese, Adh.: Adhesiveness, Min.: Minimum, Max.: Maximum, Ort. : Mean.

Peynirlerde sertlik özelliğinin farklı olması nem ve yağ oranı ile ilgilidir (Jack ve Paterson, 1992). Peynirde sakızımsıllk özelliği sertlik ile ilișkili olduğundan sertliği etkileyen etmenler sakızımsılık özelliğini de etkilemektedir (Chen vd., 1979). E10 ve E19 numaralı peynirlerde yağ ve kurumadde oranının düşük olması (Çizelge 1) sebebiyle bu peynirlere ait sertlik ve sakızımsilik değerleri de düşük olarak belirlenmiştir (Çizelge 3). Peynirlerde proteinin parçalanması sonucu elastikiyetin azaldığ1 belirtilmektedir (Hort ve Grys, 2001). Örneğin E9, E14 ve E20 numaralı peynirlerin proteoliz değerlerinin yüksek olması nedeniyle (Çizelge 2), elastikiyet değerlerinin düşük olduğu saptanmıştır (Çizelge 3). Peynirde yağ oranının artmasıyla iç yapışkanlık değeri azalmaktadır (Jong, 1987). E1, E2 ve E20 numaralı peynirlerde yağ oranının yüksek olması (Çizelge 1) iç yapışkanlık değerlerinin düşük olmasına (Çizelge 3) bağlanabilir. Şalvarcı (2015), 90 gün olgunlaştırdığ kaşar peynirlerinde sertlik, iç yapışkanlık, elastikiyet ve sakızımsılık değerlerini sırasiyla; 4305-6280 g, 0.64-0.72, 0.82$0.84 \mathrm{~mm}$ ve 2994-4009 g arasinda, Saygilı (2015), 90 gün depoladığ1 kaşar peynirlerinde sertlik, iç yapışkanlık, elastikiyet ve sakızımsılık değerlerini sirasiyla; $1988-4496 \mathrm{~g}, 0.54-0.91,2.89-4.17 \mathrm{~mm}$ ve 1073.99-3724.40 g arasında belirlemiştir. 
Peynirlerde $L^{*}$ değeri beyaz rengi ve parlakllğ1 gösteren bir parametre, $a^{*}$ değeri kırmızı rengi gösteren parametre, $b^{*}$ değeri ise sar1 rengi gösteren parametredir. Özellikle $L^{*}$ ve $b^{*}$ parametreleri peynir kalitesinin belirlenmesinde önemli olan özelliklerdir. Peynirlerin renk analiz sonuçlarına ait veriler Çizelge 3'de sunulmuştur. Ezine eski kaşar peynirlerinde $L^{*}$ değerleri incelendiğinde en yüksek $L^{*}$ değerinin 83.87 ile E13 numaralı peynirde, en düşük $L^{*}$ değerinin ise 72.56 ile E11 numaralı peynirde olduğu tespit edilmiştir (Çizelge 3). Düşük oranda tuz miktarına sahip peynirlerde $L^{*}$ değeri daha yüksek bulunmuştur (Kaya, 2002). Düşük tuz oranına sahip olan E1, E8 ve E10 numarali peynirlerde (Çizelge 1) $L^{*}$ değerinin yüksek olduğu saptanmıştır (Çizelge 3). Genel olarak olgunlaşma süresi uzadıkça peynirlerde parlaklığın arttığ1 görülmüştür. Örneğin, E3, E6, E7, E8 ve E13 numaralı peynirlerin $L^{*}$ değerlerinin (80.69-83.87) yüksek olduğu saptanmıştır. Ezine eski kaşar peynirlerinin $b^{*}$ değerlerinin geniş bir dağ 1 lim gösterdiği, en yüksek $b^{*}$ değerinin 24.74 ile E11 numaralı peynirde, en düşük $b^{*}$ değerinin ise 14.87 ile E14 numaralı peynirde olduğu saptanmıştır. Yalman (2011), 90 gün boyunca olgunlaştırdığ kaşar peynirlerinde $L^{*}$ değerini 81.86-85.13 arasında, $b^{*}$ renk değerlerini 14.78-18.34 arasında, Temizkan (2012), 90 gün boyunca olgunlaştırdığ1 kaşar peynirlerinde $L^{*}$ değerini 75.26-88.46 arasında, $b^{*}$ renk değerlerini $13.77-24.20$ arasında belirlemiştir.

Peynirlerde 33 uçucu bileşen belirlenmiş olup bunlardan 24 tanesi analiz edilen alt1 peynir örneğinde de tespit edilmiştir (Çizelge 4). Esterler, aminoasitlerce oluşturulan acı tat ve yağ asitlerince oluşturulan ransit tadı azaltarak peynirin aromasına olumlu katkı sağlamaktadır (Gallois ve Langlois, 1990). E3 ve E20 numarali peynirlerde ester miktarlarının yüksek olduğu saptanmış olup bu peynirlere ait duyusal analizler sonucu tespit edilen ransit tat da düşük bulunmuştur (Çizelge 5). Ezine eski kaşar peynirlerinde tespit edilen ve miktarı yüksek olan esterler; bütanoik asit etil ester ve hekzanoik asit etil esterdir.
Ezine eski kaşar peynirinde tespit edilen ve miktarı yüksek olan alkol bileşenleri ise 3-metil-1bütanol ve 2-pentanoldür. Alkol miktar1 en yüksek olan peynirler E6 ve E14'tür. Ercan vd. (2011), sepet peynirinde yaptı̆̆ çalışmada 1-hekzanol tespit etmiştir.

Ezine eski kaşar peynirlerinde aldehit olarak sadece 3-metil-bütanal belirlenmiş olup miktarı en yüksek olan peynir E9'dur. E3 ve E6 numaralı peynirlerde keton bileşikleri yüksek miktarlarda bulunmuş olup (Çizelge 4) bu peynirlerin olgunlaşma süreleri de uzundur. Ezine eski kaşar peynirlerinde 2-pentanon ve 2-heptanon miktarca en yüksek olan ketonlardır.

Terpenlerin, hayvanların otlatılması ile süte ve oradan peynire geçtiği belirtilmektedir (Viallon vd., 2000). Ezine eski kaşar peynirinde tespit edilen terpenler; limonen, $\alpha$-pinen olmak üzere iki tanedir. Limonen miktarı en yüksek olan peynir E3, $\alpha$-pinen miktar1 en yüksek peynir E14'tür. Ercan vd. (2011), sepet peynirinde yaptığ1 çalışmada limonen tespit etmiştir. E6, E14 ve E20 numaralı peynirlerde asit miktarlarının yüksek olduğu (Çizelge 4) saptanmış olup bu peynirlere ait proteoliz seviyesi de yüksek bulunmuştur (Çizelge 2). Ezine eski kaşar peynirlerinde tespit edilen ve miktarı yüksek olan asitler; asetik asit, bütanoik asit ve hekzanoik asittir. Yalman (2011) 90 gün depoladığ1 kaşar peynirlerinde 2-metilbütanoik asit ve 3-metil-bütanoik asit tespit etmiştir.

Yapılan duyusal analizler sonucunda peynirlerde 6 panelist tarafindan pişmiş, peyniraltı suyu, kremams1, sülfür, ransit, tuzlu, ekşi, umami, keskin (bite), buruk, ac1 aroma ve tat terimleri belirlenmiştir (Çizelge 5). Aromatik terimlerden en fazla yoğunluğa sahip olan aromalar pişmiş, peynir altı suyu, kremams1, sülfür ve ransittir. Temel tatlardan en yüksek puana sahip olan tat özelliği tuzluluktur. Bunu, ekşi, keskin ve umami tatlar takip etmektedir. 
Çizelge 4. Analiz edilen peynir örneklerinde bulunan uçucu bileşenler $(\mathrm{n}=6)$ Table 4. Volatile compounds found in analyzed cheese samples $(n=6)$

\begin{tabular}{|c|c|c|c|c|c|c|c|}
\hline \multirow{2}{*}{$\begin{array}{l}\text { Uçucu } \\
\text { Bileşenler } \\
\text { Volatile } \\
\text { Compounds }\end{array}$} & \multirow[b]{2}{*}{ RI } & \multicolumn{6}{|c|}{ Peynirler $(\mu \mathrm{g} / 100 \mathrm{~g})$ Cheeses $(\mu \mathrm{g} / 100 \mathrm{~g})$} \\
\hline & & E3 & E6 & E9 & E13 & E14 & E20 \\
\hline 2-Butanon & $<600$ & $15.13 \pm 1.14$ & - & - & - & $65.00 \pm 40.9$ & - \\
\hline Asetik asit & 600 & - & $1372.50 \pm 109.60$ & $790.50 \pm 295$ & $1093 \pm 136.9$ & $104.50 \pm 82.7$ & $5027.00 \pm 3165$ \\
\hline $\begin{array}{l}\text { 3-Metil- } \\
\text { bütanal }\end{array}$ & 645 & $0.66 \pm 0.17$ & - & $2.50 \pm 0.78$ & $0.50 \pm 0.11$ & - & - \\
\hline 1-Butanol & 657 & $0.58 \pm 0.09$ & $1.00 \pm 0.04$ & $0.50 \pm 0.14$ & $0.50 \pm 0.03$ & $1.50 \pm 0.01$ & $8.00 \pm 0.56$ \\
\hline 2-Pentanon & 685 & $16.60 \pm 1.96$ & $24.00 \pm 4.95$ & $2.50 \pm 1.06$ & $7.50 \pm 1.15$ & $11.00 \pm 2.83$ & $16.50 \pm 1.39$ \\
\hline 2-Pentanol & 699 & $5.18 \pm 1.26$ & $7.50 \pm 1.18$ & $6.00 \pm 1.22$ & $4.50 \pm 0.90$ & $11.00 \pm 2.83$ & $4.00 \pm 0.64$ \\
\hline Asetoin & 705 & $4.20 \pm 1.42$ & $7.50 \pm 1.41$ & $4.50 \pm 0.63$ & $5.00 \pm 0.77$ & $8.50 \pm 0.70$ & $4.00 \pm 0.11$ \\
\hline $\begin{array}{l}\text { 3-Metil-1- } \\
\text { bütanol }\end{array}$ & 728 & $26.89 \pm 7.61$ & $1.41 \pm 0.23$ & $4.00 \pm 1.07$ & $20.00 \pm 2.60$ & $12.50 \pm 1.41$ & $15.00 \pm 1.59$ \\
\hline Toluen & 760 & $1.01 \pm 0.32$ & $1.99 \pm 0.28$ & $0.50 \pm 0.12$ & $1.00 \pm 0.11$ & $1.00 \pm 0.02$ & $1.50 \pm 0.11$ \\
\hline Diasetil & 777 & $0.57 \pm 0.03$ & $2.70 \pm 0.04$ & $0.50 \pm 0.16$ & $1.50 \pm 0.03$ & $17.50 \pm 0.42$ & $3.00 \pm 0.31$ \\
\hline $\begin{array}{l}\text { Bütanoik asit } \\
\text { etil ester }\end{array}$ & 801 & $14.46 \pm 1.64$ & $28.12 \pm 4.70$ & $20.50 \pm 5.97$ & $17.50 \pm 2.70$ & $26.00 \pm 5.15$ & $29.00 \pm 1.37$ \\
\hline Bütanoik asit & 812 & - & $2051.05 \pm 98.2$ & $653.50 \pm 157$ & $773 \pm 186$ & $613.50 \pm 220$ & $1620.50 \pm 620$ \\
\hline $\begin{array}{l}\text { 3-Metil- } \\
\text { bütanoik asit }\end{array}$ & 847 & $1.58 \pm 0.92$ & $6.50 \pm 1.44$ & $2.50 \pm 0.42$ & $3.50 \pm 1.70$ & $6.00 \pm 1.13$ & $3.00 \pm 0.71$ \\
\hline $\begin{array}{l}\text { 2-Metil- } \\
\text { bütanoik asit }\end{array}$ & 857 & - & $6.96 \pm 1.88$ & $0.50 \pm 0.13$ & $2.00 \pm 0.12$ & $3.00 \pm 0.31$ & $2.00 \pm 0.08$ \\
\hline 1-Hekzanol & 866 & - & - & $0.50 \pm 0.20$ & $1.00 \pm 0.11$ & $1.50 \pm 0.22$ & $3.00 \pm 0.10$ \\
\hline 2-Heptanon & 857 & $15.44 \pm 3.22$ & $26.29 \pm 5.24$ & $5.00 \pm 0.66$ & $4.00 \pm 0.06$ & $7.50 \pm 0.84$ & $3.50 \pm 0.33$ \\
\hline 2-Heptanol & 900 & $3.66 \pm 0.20$ & $8.19 \pm 0.84$ & $5.00 \pm 0.72$ & $2.00 \pm 0.14$ & $6.00 \pm 0.35$ & $3.00 \pm 0.31$ \\
\hline $\begin{array}{l}\text { Oksime } \\
\text { metoksi fenil }\end{array}$ & 907 & $5.42 \pm 0.54$ & $4.39 \pm 0.55$ & $3.00 \pm 0.52$ & $4.50 \pm 0.12$ & $3.50 \pm 0.35$ & $4.00 \pm 0.21$ \\
\hline $\begin{array}{l}\text { Hekzanoik asit } \\
\text { metil ester }\end{array}$ & 923 & $2.99 \pm 0.32$ & $6.05 \pm 0.91$ & $1.00 \pm 0.31$ & $0.50 \pm 0.23$ & $1.00 \pm 0.11$ & $2.00 \pm 0.08$ \\
\hline$\alpha$-pinen & 930 & $0.58 \pm 0.17$ & $0.88 \pm 0.14$ & $0.35 \pm 0.21$ & $0.30 \pm 0.12$ & $16.00 \pm 0.28$ & $1.00 \pm 0.16$ \\
\hline$\beta$-pinen & 972 & $1.05 \pm 0.07$ & $3.74 \pm 0.84$ & - & $2.50 \pm 0.54$ & $2.00 \pm 0.21$ & $0.50 \pm 0.29$ \\
\hline $\begin{array}{l}\text { Hekzanoik } \\
\text { Asit etil ester }\end{array}$ & 999 & $32.25 \pm 2.58$ & $48.68 \pm 1.91$ & $27.50 \pm 4.04$ & $24.50 \pm 0.91$ & $16.50 \pm 0.29$ & $32.50 \pm 3.80$ \\
\hline Hekzanoik asit & 1014 & - & $1845.70 \pm 95.50$ & $755.50 \pm 204$ & $1181 \pm 113.80$ & $1977 \pm 830$ & $1112.50 \pm 214$ \\
\hline D-limonen & 1025 & $2.53 \pm 0.98$ & $2.01 \pm 0.43$ & $1.50 \pm 0.37$ & $1.50 \pm 0.32$ & $2.00 \pm 0.21$ & $1.00 \pm 0.14$ \\
\hline Eucalyptol & 1027 & $4.33 \pm 0.13$ & $4.04 \pm 0.17$ & $3.00 \pm 0.79$ & $3.00 \pm 0.22$ & $4.00 \pm 0.42$ & $2.50 \pm 0.03$ \\
\hline 2-Nonanon & 1090 & $3.96 \pm 0.02$ & $8.63 \pm 0.53$ & $1.00 \pm 0.21$ & $1.50 \pm 0.23$ & $3.00 \pm 0.22$ & $0.50 \pm 0.08$ \\
\hline Fenil etil alkol & 1109 & $1.42 \pm 0.52$ & $0.83 \pm 0.18$ & $0.50 \pm 0.04$ & $0.50 \pm 0.06$ & $0.50 \pm 0.05$ & $0.40 \pm 0.10$ \\
\hline $\begin{array}{l}\text { Oktanoik asit } \\
\text { metil ester }\end{array}$ & 1117 & $1.77 \pm 0.12$ & $2.81 \pm 0.29$ & $1.50 \pm 1.05$ & $1.00 \pm 0.02$ & $0.35 \pm 0.14$ & $1.50 \pm 0.09$ \\
\hline Kamfor & 1138 & $0.25 \pm 0.02$ & $0.50 \pm 0.08$ & $0.15 \pm 0.04$ & $0.20 \pm 0.03$ & $0.50 \pm 0.09$ & $0.35 \pm 0.07$ \\
\hline Oktanoik asit & 1186 & $1.87 \pm 1.44$ & $613.76 \pm 113.8$ & $796.50 \pm 378$ & $360.00 \pm 1.41$ & $1219.50 \pm 156$ & $389.50 \pm 109$ \\
\hline $\begin{array}{l}\text { Oktanoik asit } \\
\text { etil ester }\end{array}$ & 1197 & $1.07 \pm 0.04$ & $3.89 \pm 0.17$ & $2.50 \pm 0.63$ & $0.50 \pm 0.06$ & $2.00 \pm 0.18$ & $2.00 \pm 0.24$ \\
\hline Dekanoik asit & 1372 & - & $21.17 \pm 5.58$ & $217.50 \pm 122$ & $9.00 \pm 4.47$ & $188.00 \pm 27.60$ & - \\
\hline $\begin{array}{l}\text { Dekanoik asit } \\
\text { etil ester }\end{array}$ & 1396 & $0.30 \pm 0.07$ & $0.77 \pm 0.21$ & $1.00 \pm 0.65$ & $0.25 \pm 0.06$ & $0.50 \pm 0.18$ & $0.50 \pm 0.12$ \\
\hline
\end{tabular}

RI: Alikonma indeksi, -: belirlenemedi.

$\mathrm{RI}$ : Retention index, -: not determined. 
Çizelge 5. Peynirlerin duyusal özellikleri $(\mathrm{n}=20)$

Table 5. Sensory properties of the cheeses $(n=20)$

\begin{tabular}{|c|c|c|c|c|c|c|c|c|c|}
\hline $\begin{array}{l}\text { Peynir } \\
\text { Chesee }\end{array}$ & $\begin{array}{l}\text { Piş. } \\
\text { Cooked }\end{array}$ & $\begin{array}{l}\text { PAS } \\
\text { Whey }\end{array}$ & $\begin{array}{l}\text { Kre. } \\
\text { Creamy }\end{array}$ & $\begin{array}{l}\text { Sül. } \\
\text { Sulfur }\end{array}$ & Ran. & $\begin{array}{l}\text { Tuzlu } \\
\text { Salty } \\
\end{array}$ & $\begin{array}{l}\text { Ekşi } \\
\text { Sour }\end{array}$ & & $\begin{array}{l}\text { Keskin } \\
\text { Bite }\end{array}$ \\
\hline E1 & $33 \pm 0.40$ & $3.33 \pm 0.81$ & $4.83 \pm 0.40$ & - & - & $6.00 \pm 0.00$ & $1.41 \pm 0.49$ & & - \\
\hline E2 & & & & - & - & & & & - \\
\hline E3 & & & & $0.66 \pm 0.51$ & $1.41 \pm 0,58$ & & & & \\
\hline E4 & $2.50 \pm 0.54$ & $3.66 \pm 0.51$ & $3.58 \pm 0.91$ & $1.25 \pm 0.88$ & & & $2.16 \pm 0.40$ & & \\
\hline E5 & $0 \pm 0.54$ & $2.00 \pm 0$ & $4.83 \pm 0.75$ & & & & $1.75 \pm 0$ & & \\
\hline E6 & $3.00 \pm 0.00$ & $2.83 \pm 0.40$ & $4.08 \pm 0.66$ & $5.00 \pm 0.00$ & $5.00 \pm 0.00$ & & $1.25 \pm 0.41$ & & $3.33 \pm 0.40$ \\
\hline E7 & $00 \pm 0.00$ & $3.83 \pm 0.40$ & $4.33 \pm 0.51$ & $2.00 \pm 0$. & $0.66 \pm$ & & $0.26 \pm 0.02$ & $1.08 \pm 0.66$ & - \\
\hline E8 & $3.66 \pm 1.03$ & $2.66 \pm 0.81$ & $4.83 \pm 0.40$ & $1.00 \pm 0.31$ & $0.41 \pm 0.20$ & 0.51 & $0.66 \pm 0.25$ & $0.46 \pm 0.25$ & - \\
\hline E9 & $2.83 \pm 0.75$ & $2.16 \pm 0.40$ & $3.00 \pm 0.63$ & $2.33 \pm 0.25$ & $2.33 \pm 0.51$ & $10.50 \pm 0.54$ & $1.91 \pm 0.20$ & $2.50 \pm 0.31$ & $0.16 \pm 0.08$ \\
\hline E10 & $2.08 \pm 0.49$ & $2.00 \pm 0.00$ & $3.00 \pm 0.00$ & $1.00 \pm 0.31$ & $3.66 \pm 0.51$ & .00 & $1.33 \pm 0.25$ & $1.83 \pm 0.81$ & $2.91 \pm 0.20$ \\
\hline E11 & $.00 \pm 0.00$ & $3.16 \pm 0.40$ & $3.83 \pm 0.40$ & $2.75 \pm 0.88$ & $0.91 \pm$ & .49 & $0.91 \pm 0.37$ & $2.25 \pm 0.41$ & $0.41 \pm 0.37$ \\
\hline E12 & $3.16 \pm 0.40$ & $3.33 \pm 0.81$ & $2.91 \pm 0.66$ & $1.75 \pm 0.41$ & $0.88 \pm 0.49$ & $8.08=$ & $1.00 \pm 0.31$ & $1.25 \pm 0.41$ & $0.66 \pm 0.25$ \\
\hline E13 & $3.25 \pm 0.41$ & $3.66 \pm 0.51$ & $3.08 \pm 0.49$ & $0.91 \pm 0.2$ & 1.08 & & $0.91 \pm 0$ & .25 & $0.41 \pm 0.20$ \\
\hline E14 & $5 \pm 0.61$ & $2.75 \pm 0.61$ & $2.91 \pm 0.66$ & $1.91 \pm 0.86$ & $1.91=$ & .66 & $1.58 \pm 0.37$ & $2.25 \pm 0.52$ & $1.00 \pm 0.44$ \\
\hline E15 & $2.58 \pm 0.49$ & $2.66 \pm 0.60$ & $3.16 \pm 0.40$ & $0.75 \pm 0.41$ & $0.91 \pm 0$ & 0.54 & $1.08 \pm 0.66$ & $1.08 \pm 0.37$ & $0.25 \pm 0.00$ \\
\hline E16 & $2.83 \pm 0.25$ & $3.08 \pm 0.80$ & $2.66 \pm 1.21$ & $1.16 \pm 0.75$ & $1.33 \pm 0.60$ & \pm 0.88 & $1.91 \pm 0.20$ & $1.83 \pm 0.25$ & $1.41 \pm 0.58$ \\
\hline E17 & $3.16 \pm 0.40$ & $3.16 \pm 0.40$ & $2.41 \pm 0.73$ & $0.91 \pm 0.37$ & $2.33 \pm 0.87$ & $6.58 \pm 0.66$ & $1.83 \pm 0.25$ & $1.55 \pm 0.54$ & $0.66 \pm 0.40$ \\
\hline E18 & $2.83 \pm 0.40$ & $2.83 \pm 0.40$ & $2.58 \pm 0.66$ & $0.75 \pm 0.27$ & $0.88 \pm 0.20$ & $6.83 \pm 0.75$ & $2.16 \pm 0.68$ & $2.16 \pm 0.40$ & $2.50 \pm 0.63$ \\
\hline E19 & $3.91 \pm 0.20$ & $2.75 \pm 0.41$ & $2.08 \pm 0.66$ & $1.08 \pm 0.49$ & $1.00 \pm 0.31$ & $8.41 \pm 0.91$ & $2.50 \pm 0.54$ & $1.33 \pm 0.51$ & $2.75 \pm 0.41$ \\
\hline E20 & $3.33 \pm 0.81$ & $2.58 \pm 0.80$ & $2.58 \pm 0.49$ & $2.58 \pm 0.37$ & $2.75 \pm 0.61$ & $7.25 \pm 0.41$ & $1.83 \pm 0.25$ & \pm 0.20 & $4.91 \pm 0.20$ \\
\hline Min. & $2.08 \pm 0.49$ & $2.00 \pm 0.00$ & $2.08 \pm 0.66$ & - & - & $6.00 \pm 0.00$ & $0.26 \pm 0.02$ & $0.25 \pm 0.15$ & - \\
\hline Mak./Max & $4.00 \pm 0.00$ & $3.83 \pm 0.40$ & $4.83 \pm 0.75$ & $5.00 \pm 0.00$ & $5.00 \pm 0.00$ & $10.50 \pm 0.54$ & $2.50 \pm 0.54$ & $2.91 \pm 0.20$ & $4.91 \pm 0.20$ \\
\hline Ort./Mean & $3.10 \pm 0.45$ & $2.58 \pm 0.52$ & $3.47 \pm 0.57$ & $1.47 \pm 0.40$ & $1.68 \pm 0.41$ & $7.90 \pm 0.54$ & $1.54 \pm 0.34$ & $1.53 \pm 0.38$ & $1.25 \pm 0.24$ \\
\hline
\end{tabular}

E: Ezine eski kaşar peyniri, Piş.: Pişmiş, PAS: Peyniraltı suyu, Kre.: Kremamsı, Sül.: Sülfür, Ran.: Ransit, Min.: Minimum, Mak.: Maksimum, Ort.: Ortalama. -: belirlenemedi.

E: Ezine aged kasar cheese, Piș.: Cooked, PAS: Whey, Kre.: Cream, Sül.: Sulfur, Ran: Rancid, Min.: Minimum, Max.: Maximum, Ort:: Mean.-: not determined

Pişmiş özelliği bakımından en yüksek puan E7 numaralı peynirde, en düşük puan E10 numaralı peynirde, peynir altı suyu özelliği bakımından en yüksek puan 3.83 puan ile E7 numaralı peynirde, en düşük puan1 2 ile E5 ve E10 numaralı peynirde, kremamsı özellik olarak en yüksek puan E5 ve E8 numaralı peynirlerde, tuzluluk özelliği bakımından en yüksek puan 10.5 ile E9 ve E15 numaralı peynirlerde, en düşük puan ise E1 numaralı peynirde belirlenmiştir. Yalman (2011), 90 gün depoladığ1 kaşar peynirlerinde duyusal analizler sonucu pişmiş, peyniraltı suyu, kremamsı ve tuzlu terimlerinin değerleri sirasıyla; 2.40-3.21, 0.41 $3.31,2.90-3.12$ ve $1.28-1.56$ olarak bulmuştur.

\section{SONUÇ}

Ezine eski kaşar peyniri üretiminde kullanılan süt türleri ve süt karışım miktarları farklılık gösterebilmektedir. Bu faktörler peynirlerin bileşimi, fiziksel, kimyasal ve duyusal özelliklerinde de farkliliklara neden olabilmektedir. Ezine eski kaşar peyniri ağırlıklı olarak koyun sütünden üretilmesine rağmen çeşitli oranlarda süt karışımlarından oluşması peynirin kendine özgü karakteristik uçucu bileşen profiline etki etmektedir. Elde edilen bulgular yöresel olarak üretilen Ezine eski kaşar peynirinin bazı karakteristik özelliklerinin ortaya konması ve tanitilmasi konusunda temel bilgiler sağlamaktadır. 


\section{TEŞEKKÜR}

Bu makale Muhammed Ali DOĞAN'in "Ezine Eski Kaşar Peynirinin Karakteristik Bazı Özelliklerinin Belirlenmesi” başlıklı yüksek lisans tezinden (Çanakkale Onsekiz Mart Üniversitesi, Fen Bilimleri Enstitüsü, YÖK Tez No: 527733) üretilmiştir. Çalışmanın gerçekleştirilmesinde desteklerini esirgemeyen Ezine eski kaşar peyniri üreticisi firmalara ve duyusal değerlendirmelerde katk1 sağlayan panelistlere teşekkür ederiz.

\section{KAYNAKÇA}

AOAC, (2000). Official Methods of Analysis of $A O A C$ International. Volume I, II. 17. Edition, Gaithersburg, USA.

Avşar, Y. K., Karagül, Y. Y., Drake, M. A., Singh, T. K., Yoon, Y., Cadwallader, K. R. (2004). Characterization of nutty flavor in Cheddar cheese. J Dairy Sci, 87: 1999-2010.

Aydemir, O. (2010). Kars kaşar peynirinin karakterizasyonu. Ondokuz Mayis Üniversitesi Fen Bilimleri Enstitüsü, Samsun, Türkiye, 128 s.

Baspinar, E., Mendes, M., Camdeviren, H. (2000). Multidimensional scaling analysis and its usage. Biyoteknoloji (KUKEM), 24: 89-98.

Bhale, S., No, H. K., Prinyawiwatkul, W., Farr, A. J., Nadarajah, K., Meyers, S. P. (2003). Chitosan coating improves shelf life of eggs. J Food Sci, 68 (7): 2378-2383.

Bradley, Jr. R. L., Arnold, Jr. E., Barbano, D. M., Semerad, R. G., Smith, D. E., Vines, B.K. (1992). Chemical and physical methods. In standard methods for the examination of dairy products, ed: Marshall, R. T., Am Public Health Assoc, Washington D.C., 433-531.

Chen, A. H., Larkin, J. W., Clark, C. J., Irwin, W. E. (1979). Textural analysis of cheese. J Dairy Sci, 62: 901-907.

Doğan, N. (2010). Erzurum piyasasında satılan kaşar peynirlerinin bazı mikrobiyolojik, fiziksel ve kimyasal özelliklerinin tespiti. Atatürk Üniversitesi Fen Bilimleri Enstitüsü, Erzurum, 41 s.

Ercan, D., Korel, F., Yüceer, Y. K., Kınık Ö. (2011). Physicochemical, textural, volatile and sensory profiles of traditional Sepet cheese. $J$ Dairy Sci, 94:4300-4312.

Fırat, N. (2006). Çiğ ve pastörize sütten üretilen kaşar peynirlerinin olgunlaşma süresince bazı mikrobiyolojik, fiziksel ve kimyasal özelliklerinin belirlenmesi. Atatürk Üniversitesi Fen Bilimleri Enstitüsü, Erzurum, $76 \mathrm{~s}$.

Folkertsma, B., Fox, P. F. (1992). Use of the Cdninhydrin reagent to assess proteolysis in cheese during ripening. J Dairy Res, 59: 217-224.

Gallois, A., Langlois, D. 1990. Volatile compounds of French blue cheeses. Le Lait, 70: 89-106.

Hort, J., Grys, G. L. (2001). Developments in the textural and rheological properties of UK Cheddar cheese during ripening. Int Dairy J, 11: 475-481.

IDF, (1993). Milk determination of nitrogen content. IDF: 20B, International Dairy Federation, Belgium.

Jack, F. R., Paterson A. (1992). Texture of hard cheeses. Trend in Food Sci Technol, 3: 160-164.

Jarrett, W. D., Aston, J. W., Dulley, J. R. (1982). A simple method for estimating free amino acids in Cheddar cheese. Aust J Dairy Technol, 37: 55-58.

Jong, L. (1987). The influence of the moisture content on the consistency and protein breakdown of cheese. Neth Milk Dairy J, 32: 1-14.

Kaya, S. (2002). Effect of salt on hardness and whiteness of Gaziantep cheese during short-term brining. J Food Eng, 52: 155-159.

Kesenkaş, H., Dinkçi, N., Seçkin, A. K., Kinik, Ö., Gönç, S. (2009). The effect of using a vegetable fat blend on some attributes of kashar cheese. Grasas Aceites, 60 (1): 41-47.

Koca, N. (2002). Baz1 yağ ikame maddelerinin yağ1 azaltılmıs taze kaşar peynirinin nitelikleri üzerine etkileri. Ege Üniversitesi Fen Bilimleri Enstitüsü, İzmir, $227 \mathrm{~s}$.

Kruskal, J. B. (1964). Multidimensional scaling by optimizing goodness of fit to a nonmetric hypothesis, Psychometrika, 2: 1-27. 
Kuchroo, C. N., Fox, P. F. (1982). Soluble nitrogen in cheddar cheese: Comparison of extraction procedures. Milchwissenschaft, 37: 331335.

Madkor, S., Fox, P. F., Shalabi, S. I., Metwalli, N. H. (1987). Studies on the ripening of stilton cheese: Proteolysis. Food Chem, 25: 13-29.

McSweeney, P. L. H., Fox, P. F., Lucey, J. A., Jordan, K. N., Cogan, T. M. (1993). Contribution of the indigenous microflora to the maturation of cheddar cheese, Int Dairy J, 3: 613-634.

Meilgaard, M., Civille, G. V., Carr, B. T. (1999). Descriptive analysis techniques. Sensory Evaluation Techniques. 3. Edition CRC Press, Inc. Boca Raton, FL. 161-170.

Metin, M., (2006). Süt Teknolojisi. E.Ü. Mühendislik Fakültesi, Yayın No:33, Ege Üniversitesi Basımevi, İzmir, 623 s.

NIST, (2008). NIST/EPA/NIH Mass spectral library (NIST 08). National Institute of Standards and Technology Standard Reference Data Program, Gaithersburg, MD 20899.

Omar, M. M., El-Zayat, A. I. (1986). Ripering changes of kashkaval cheese made from Cow's milk. Food Chem, 22: 83-94.

Polychroniadou, A., Michaelidou, A., Paschaloudis, N. (1999). Effect of time, temperature and extraction method on trichloroacetic acid-soluble nitrogen of cheese. Int Dairy J, 9: 559-568.

Renner, E. (1986). Milchpraktikum. Fachgebiet Milchwissenschaft Justic-Liebing Universitat Giessen, 57 p.

Say, D. (2008). Haşlama suyunun tuz konsantrasyonu ve depolama süresinin kașar peynirinin özellikleri üzerine etkileri. Cukurova Üniversitesi Fen Bilimleri Enstitüsü, Adana, 131 s.

Saygıll, D. (2015). Mersin uçucu yağ1 içeren yenilebilir film üretimi ve kaşar peynirinin muhafazasında mikrobiyal inaktivasyona etkisi. Ege Üniversitesi Fen Bilimleri Enstitüsü, İzmir, $98 \mathrm{~s}$.
Şalvarc1, M. (2015). Farklı pH değerlerindeki telemelerden farklı üretim yöntemleriyle üretilen kaşar peynirlerinin bazı özelliklerinin belirlenmesi. Selçuk Üniversitesi Fen Bilimleri Enstitüsü, Konya, $76 \mathrm{~s}$.

Temizkan, R. (2012). Kaşar peynirinin bileşim, proteoliz, fonksiyonel ve duyusal özellikleri üzerine inek, koyun ve keçi sütü kullanımının etkisi. Çanakkale Onsekiz Mart Üniversitesi Fen Bilimleri Enstitüsü Çanakkale, $80 \mathrm{~s}$.

TS. (1978). Peynirde yă miktarı tayini. (VanGulik Metodu): Türk Standartları Enstitüsü. TS 3046. Ankara.

TS. (1989). Beyaz peynir standardı, Türk Standartları Enstitüsü. TS 591. Ankara.

TSE (1999). Kaşar peyniri standardı, Türk Standartlar Enstitüsü. TS 3272, Ankara.

Viallon, C., Martin, B., Verdier, M. I., Pradel, P. G., J. P., Coulon, J. B., Berdague, J. L. (2000). Transfer of monoterpenes and sesquiterpenes from forages into milk fat. Lait, 80: 635-641.

Wiley, (2005). Wiley Registry of Mass Spectral Data 7. Edition (Fred. W. McLafferty) ISBN: 9780471473251, 2005 (CD-ROM).

Yalman, M. (2011). Kaşar benzeri peynir üretimi: fiziksel, kimyasal ve duyusal özellikleri. Çanakkale Onsekiz Mart Üniversitesi Fen Bilimleri Enstitüsü, Çanakkale, $57 \mathrm{~s}$.

Yaşar, K. (2000). Vakum paketlenmiș kașar peyniri yapımında uygulanan farklı proseslerinin kaşar peynirinin çeşitli özelliklerine etkisi. Trakya Üniversitesi Fen Bilimleri Enstitüsü Tekirdağ, 76 s.

Yașar, K. (2007). Farklı pıhtılaștırıcı enzim kullanımının ve olgunlașma süresinin kașar peynirinin özellikleri üzerine etkisi. Çukurova Üniversitesi Fen Bilimleri Enstitüsü Adana, 134 s.

Yüzbaş1, N. (1996). Pastörize edilmiş starter kültür katılmıs sütlerden glukono delta lakton (GDL) kullanilarak elde edilen beyaz peynirlerin bazı nitelikleri üzerinde araştırmalar. Ankara Üniversitesi Fen Bilimleri Enstitüsü Ankara, 80 s. 